\title{
Cesare Beccaria: back to the future of law and economics
}

\author{
Giovanni B. Ramello ${ }^{1}$ Alain Marciano ${ }^{2}$
}

Published online: 2 November 2018

(c) Springer Science+Business Media, LLC, part of Springer Nature 2018

Crime is currently a flourishing domain of investigation in law and economics, to the point that many studies on this topic have trespassed the boundaries of the discipline and become attractive even for well-known mainstream economics journals. Newly available datasets have made it possible to refresh our current understanding of crime and test some of the theoretical tenets dating back to the visionary thinker Cesare Beccaria (1738-1794). More than 250 years ago, he published the seminal book Trattato Dei Delitti e delle Pene, which provided a new and modern way to look at punishment and sanctions.

Born nobleman in Milan, Italy, Cesare Bonasena, Marquis of Beccaria, was exposed to many important traditions of thought which imparted to him the skills to become a 'peaceful' revolutionary in the way of looking at law and institutions. Raised by Jesuits in the pure orthodox Catholic culture, as was then customary in the Italian peninsula, he also received a robust education in mathematics-for which he demonstrated an extraordinary aptitude, to the point that his schoolmates gave him the nickname "Newtoncino" (i.e., little Newton; Mauri 1933). He then graduated in Law at the University of Pavia, becoming an expert in legal institutions.

In addition to the above, he was likewise exposed to German culture, since Milan was part of the Habsburg Empire at that time, and also had the opportunity to learn the new approach developed by the French Enlightenment. In short order, thanks to the peculiar historical situation characterizing Europe-and particularly Milan-in that period, he became a champion of this universal knowledge, which he successfully applied as a professor of Cameral Sciences (Public Economics) appointed by Marie Therese of Austria at the Palatine Schools in Milan (1768-1771), and later as an advisor of the government (1771-1794). In both roles, he demonstrated an original viewpoint that led to important innovations. These two positions moreover show how, though Beccaria is most well-known worldwide for his essay on crime and punishment, he was equally influential

Giovanni B. Ramello

giovanni.ramello@uniupo.it

1 DiGSPES, Università del Piemonte Orientale, Alessandria, Italy

2 MRE and University of Montpellier, Montpellier, France 
through his approach to public economics, which remained the core of his activity as an academic and government advisor (Mauri 1933).

His broad culture, ranging from the ancient Roman roots of law to the modern scientific way of thinking of the Enlightenment, and also encompassing a familiarity with rigorous mathematical reasoning, led him to develop ante-litteram what later became the law and economics approach. Indeed, his contribution to the social sciences extends well beyond the boundaries of crime, because he essentially established a methodology and world view-a Weltanschauung - concerning the social role of institutions and individual action, which predated law and economics by more than two centuries.

So, despite being still mostly known today for his booklet on crime, and the positions propounded therein against the death sentence and cruelty in punishment, Beccaria's real contribution to science has been in direction of changing our way of thinking about institutions, by promoting the alignment of private incentives and the public interest. This is precisely the core of the law and economics approach.

Ultimately, although Beccaria might seem to be chiefly concerned with human rights and individual protections, in reality the most relevant issue to him with respect to punishment was its incentive consequence, meaning its ability to act as a deterrent. This orientation can be grasped repeatedly in the essay. For instance, when he writes that " $[t]$ he end of punishment, therefore, is no other, than to prevent others from committing the like offence." $(1778,51)$. Beccaria goes on, "[s]uch punishments, therefore, and such a mode of inflicting them, ought to be chosen, as will make strongest and most lasting impressions on the minds of others, with the ideal torment to the body of the criminal." $(1778,51)$.

Whether this represents a utilitarian theory of punishment, as a handful of commentators have claimed (see e.g. Young 1983), his orientation was always towards the public good, since, as he asserted, "the idea of public utility ... is the foundation of human justice." (1778, 37).

This attitude of looking at punishment through an economics lens, by considering the social perspective and taking the incentives system as a benchmark, was a major reference-point in the intellectual training of the acknowledged founding fathers of law and economics, two European transplanted in the US: Ronald Coase and Guido Calabresi (Marciano and Ramello 2017). To be clear, we do not have any intention here to claim that law and economics is a European discipline. Rather, we maintain that the approach is a tree whose seed sprang from a time-honored European tradition. This of course does not cancel out the US specificity, but it does explain the universality of law and economics and its worldwide recognition. It is in effect trivial to remark that its two founding fathers were European expatriates, one of whom was born and raised in a highly educated family coming from Beccaria's Milan (Ramello 2016). But these European roots, and Beccaria's legacy, also permeate the literature to a deeper extent. It is worth noting that the "Chicagoan" Gary Becker, the applauded pioneer of law and economics of crime (although he never regarded himself as such), in his paper on Crime and Punishment: An Economic Approach actually wrote that "should the reader be repelled by the apparent novelty of an 'economic' framework for illegal behavior, let him recall that two important 
contributors to criminology during the eighteenth and nineteenth centuries, Beccaria and Bentham, explicitly applied an economic calculus" (1968, p. 209).

This is precisely what Beccaria did, to the point that Becker's contribution-as he himself frankly admitted-resembles more a refreshment and a modern take on the pre-existing work. In fact, as Becker points out: "Unfortunately, such an approach has lost favor during the last hundred years, and my efforts can be viewed as a resurrection, modernization, and thereby I hope improvement on these much earlier pioneering studies." (Becker 1968, 209). Without a doubt, it can be said that Becker succeeded, not only in contributing to the emergence of an economic analysis of law, but also in making Cesare Beccaria the forerunner of this new field of research.

Other scholars have associated Beccaria's name with law and economics. Posner (1973) also refers to Beccaria as a founder of the field, and we could add a few other references. Yet, Beccaria's name and work have not, to date, been extensively discussed in law and economics, and this is one good reason to devote a special issue to him. Another reason is to enrich our knowledge of Beccaria's disruptive ideas. This is precisely what the contributors to this special issue tell us.

The articles presented here begin with an effective overview of Beccaria's work, provided by Bessler's (2016) contribution, which discusses its main elements and his worldwide diffusion. Then Miceli (2016) further develops the impact of Beccaria's contribution with special reference to punishment, the concept of proportionality, and how it is currently applied in relation to the economic theory, while White (2016) identifies a neglected though important nuance in Beccaria's research on crime, that is to say, the central role played by psychology. This makes the Italian scholar possibly the first scientist to adopt the behavioral law and economics perspective. The idea is further disentangled by Mulder's (2016) article which discusses the peculiar ability of punishment to convey moral norms, under certain circumstances.

Although statistics have brought a new lease of life to the analysis of crime, Buonanno et al. (2017) alerts the reader to the problems that may arise when using data, owing to the fact that crime is by its very nature a hidden phenomenon. Consequently, statistics necessarily suffer from shortcomings resulting from misreporting or other measurement errors.

Last, we decided to conclude the issue with an independently-submitted paper, which in our view perfectly fits and completes the overview provided in this issue: Yahagi (2018) opens the way to a fascinating - and so far not intensively discussed-perspective on the industrial organization of crime, focusing on criminal organizations and their effects on social welfare. A large part of this chapter of knowledge remains still to be written and-in the footsteps of Beccaria-we invite scholars to walk this way.

\section{References}

Beccaria, C. (1778). An essay on crimes and punishment. Edinburg: Donaldson. 
Becker, G. S. (1968). Crime and punishment: An economic approach. Journal of Political Economy, 76(2), 169-217.

Bessler, J. D. (2016). The economist and the enlightenment: How Cesare Beccaria changed Western civilization. European Journal of Law and Economics. https://doi.org/10.1007/s10657-016-9546-Z.

Buonanno, P., Drago, F., Galbiati, R., \& Vertova, P. (2017). How much should we trust crime statistics? A comparison between EU and US. European Journal of Law and Economics. https://doi. org/10.1007/s10657-017-9555-6.

Marciano, A., \& Ramello, G. B. (2017). The judge, the academic and the public intellectual: The totemic scholarship of Richard A. Posner. European Journal of Law and Economics, 43, 392-398.

Mauri, A. (1933). La Cattedra di Cesare Beccaria. Archivio Storico Italiano, 91(4), 199-262.

Miceli, T. J. (2016). The economist and the enlightenment: How Cesare Beccaria changed Western civilization. European Journal of Law and Economics. https://doi.org/10.1007/s10657-016-9524-5.

Mulder, L. B. (2016). When sanctions convey moral norms. European Journal of Law and Economics. https://doi.org/10.1007/s10657-016-9532-5.

Posner, R. (1973). Economic analysis of law. Boston: Little, Brown and Company.

Ramello, G. B. (2016). The past; present and future of comparative law and economics. In T. Eisenberg \& G. B. Ramello (Eds.), Comparative law and economics. Cheltenham: Edward Elgar PublishingMA.

White, M. D. (2016). The neglected nuance of Beccaria's theory of punishment. European Journal of Law and Economics. https://doi.org/10.1007/s10657-016-9530-7.

Yahagi, K. (2018). Welfare effects of forming a criminal organization. European Journal of Law and Economics. https://doi.org/10.1007/s10657-018-9600-0.

Young, D. (1983). Cesare Beccaria: Utilitarian or redistributivist? Journal of Criminal Justice, 11(4), 317-326. 